\title{
Pengaruh Perputaran Kas dan Perputaran Piutang terhadap Profitabilitas pada Perusahan Sub Sektor Perkebunan di BEI
}

\author{
Dwi Putri Ratnasari ${ }^{1 *}$, Wayan Cipta ${ }^{2}$ iD \\ ${ }^{123}$ Program Studi Manajemen, Fakultas Ekonomi, Universitas Pendidikan Ganesha, Singaraja, Indonesia \\ *dwiputri1242@gmail.com ${ }^{1 *}$
}

\section{Abstrak}

Penelitian ini bertujuan untuk menguji pengaruh (1) perputaran kas dan perputaran piutang terhadap profitabilitas, (2) perputaran kas terhadap profitabilitas, (3) perputaran piutang terhadap profitabilitas pada perusahaan sub sektor perkebunan. Desain penelitian yang digunakan yaitu kuantitatif kausal. Subjek penelitian adalah perusahaan sub sektor perkebunan yang terdaftar di Bursa Efek Indonesia dan objek penelitian yaitu perputaran kas, perputaran piutang, dan profitabilitas. Data dikumpulkan dengan pencatatan dokumen, dan dianalisis dengan analisis regresi linier berganda. Hasil penelitian menunjukkan bahwa (1) perputaran kas dan perputaran piutang berpengaruh signifikan terhadap profitabilitas, (2) perputaran kas berpengaruh positif dan signifikan terhadap profitabilitas, (3) perputaran piutang berpengaruh positif dan signifikan terhadap profitabilitas, artinya secara keseluruhan bahwa besar kecilnya profitabilitas perusahaan dipengaruhi oleh perputaran kas dan perputaran piutang.

Kata Kunci : Perputaran Kas, Perputaran Piutang, dan Profitabilitas

\section{Abstract}

This study aims to examine the effect of (1) cash turnover and accounts receivable turnover on profitability, (2) cash turnover on profitability, (3) accounts receivable turnover on profitability in plantation sub-sector companies. The research design used is causal quantitative. The research subjects were plantation sub-sector companies listed on the Indonesia Stock Exchange and the objects were cash turnover, accounts receivable turnover, and profitability. Data were collected by documents recording, and analyzed by multiple linear regression analysis. The results showed that (1) cash turnover and accounts receivable turnover had a significant effect on profitability, (2) cash turnover has a positive and significant effect on profitability, (3) accounts receivable turnover has a positive and significant effect on profitability, this means that overall the size of the company's profitability is influenced by cash turnover and accounts receivable turnover.

Keywords: Accounts Receivable Turnover, Cash Turnover, and Profitability

\section{Pendahuluan}

Seiring dengan perkembangan zaman, tingkat persaingan di bidang bisnis semakin ketat menyebabkan perusahaan yang ada harus dapat mengelola aktiva yang dimiliki dengan efektif dan efisien. Dalam persaingan yang semakin ketat perusahaan harus memiliki daya saing yang kuat untuk dapat mempertahankan kelangsungan hidupnya dan dapat mencapai tujuan perusahaan yaitu memperoleh laba. Laba merupakan hasil yang diperoleh perusahaan atas apa yang dilakukan pada periode tertentu. Besar kecilnya laba yang diperoleh tergantung dari bagaimana perusahaan tersebut mengelola aktiva yang dimilikinya. Semakin baik penggunaan aktiva maka laba yang didapat semakin tinggi hal ini diikuti dengan meningkatnya profitabilitas.

Sektor pertanian adalah salah satu sektor yang terdaftar di Bursa Efek Indonesia (BEI). Indonesia merupakan negara pertanian yang artinya bahwa sektor pertanian memiliki peran

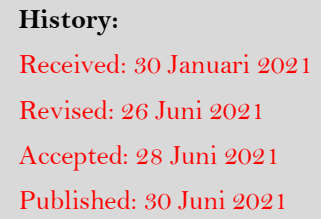


yang sangat penting dalam pertumbuhan ekonomi. Salah satu sub sektor yang memberikan kontribusi terhadap PDB sektor pertanian adalah sub sektor Perkebunan. Sub sektor perkebunan merupakan sub sektor yang dapat menjadi andalan dalam kegiatan ekspor. Sub sektor perkebunan juga dapat meningkatkan devisa negara dan meningkatkan kesejahteraan rakyat Indonesia. Perkembangan sub sektor perkebunan yang baik akan dapat memberikan keuntungan bagi perusahaan. Hal ini akan berdampak pada banyaknya investor yang akan berinvestasi.

Rasio profitabilitas merupakan rasio yang digunakan untuk megukur bagaimana perusahaan dapat menghasilkan laba (Kasmir, 2011). Profitabilitas disuatu perusahaan dapat diukur dengan menggunakan laba bersih yang diterima dengan aktiva yang digunakan secara efisien. Profitabilitas sangat penting dari pada laba yang tinggi, karena penerimaan laba yang besar belum mencerminkan ukuran perusahaan dapat bekerja dengan baik.

Pada obsevasi awal yang dilakukan didapatkan nilai profitabilitas pada sub sektor perkebunan mengalami penurunan nilai profitabilitas yang sangat tajam dibandingkan dengan sub sektor lainnya pada tahun 2017 - 2019. Rendahnya profitabilitas pada sub sektor perkebunan diduga disebabkan oleh perputaran kas dan perputaran piutang. Hal ini sejalan dengan teori yang dikemukakan oleh Riyanto (1995) bahwa tinggi rendahnya tingkat profitabilitas dipengaruhi oleh modal kerja. Komponen modal kerja terdiri dari kas dan piutang yang dapat mempengaruhi keuntungan/ profitabilitas. Teori ini sejalan dengan hasil penelitian yang dilakukan Nurmawardi dan Lubis (2018)

Pertama, yang diduga mempengaruhi profitabilitas adalah perputaran kas. Menurut Gill dalam (Kasmir, 2010) rasio perputaran kas memiliki fungsi untuk mengukur tingkat tersedianya modal yang ada di perusahaan untuk membayar hutangnya dan untuk membiayai penjualannya. Dengan mengetahui tingkat perputaran kas yang ada pada perusahaan, maka dapat mengetahui bagaimana penggunaan kasnya. Semakin tinggi tingkat perputaran kasnya maka semakin baik, karena kas digunakan dengan efektif dan efisien, hal ini akan berdampak pada profitabilitas yang didapat oleh perusahaan.. Pernyataan ini didukung penelitian yang dilakukan oleh Yulistiani dan Suryantini (2016) dan Narayana (2013) di mana hasil dari penelitian tersebut bahwa perputaran kas berpengaruh positif dan signifikan terhadap profitabilitas. Berbeda dengan penelitian yang dilakukan oleh Ulum dan Hartono (2017) dan Priantiningtias dan Sitohang (2017) bahwa perputaran kas berpengaruh negatif terhadap profitabilitas.

Kedua, yang diduga mempengaruhi profitabilitas adalah perputaran piutang. Piutang juga merupakan bagian dari modal kerja yang akan selalu terus berputar, dimana piutang akan tertagih pada saat waktu yang telah ditentukan. Periode perputaran piutang tergantung dari syarat pembayarannya. Semakin lama syarat pembayaran tersebut maka semakin lama modal kembali menjadi kas karena masih terikat terhadap piutang. Semakin banyak jumlah piutang yang diberikan, maka hal tersebut juga akan meningkatkan laba/ profitabilitas (Riyanto, 1995 Penyataan ini sesuai dengan penelitian yang dilakukan oleh Putra dan Wirajaya (2013) dan Nurmawardi dan Lubis (2018) bahwa perputaran piutang berpengaruh positif dan signifikan terhadap profitabilitas. Berbeda dengan penelitian yang dilakukan oleh Priantiningtias dan Sitohang (2017) dan Santoso (2013) bahwa perputaran piutang memiliki pengaruh negatif dan signifikan terhadap profitabilitas.

Berdasarkan dari laporan keuangan Sub Sektor Perkebunan Tahun 2017 - 2019 ditemukan beberapa permasalahan pada perputaran kas, perputaran piutang dan profitabilitas perusahaan pada sub sektor perkebunan yang terdaftar di Bursa Efek Indonesia (BEI) tahun 2017 - 2019. Pada perusahaan Sampoerna Agro Tbk mengalami peningkatan perputaran kas pada tahun 2019 sebesar 2,11\% dari 2,76 kali pada tahun 2018 menjadi 4,87 kali pada tahun 2019. Namun peningkatan perputaran kas tersebut tidak diikuti dengan peninkatan 
profitabilitas. Hal ini tidak sesuai dengan teori Riyanto (1995) menyatakan bahwa semakin tinggi tingkat perputaran kas maka semakin tinggi tingkat penggunaan kasnya dan akan dapat memperoleh laba yang semakin tinggi pula.

Pada perusahaan Astra Agro Lestari Tbk mengalami peningkatan perputaran piutang pada tahun 2018 sebesar $0,59 \%$ dari 32,20 kali pada tahun 2017 menjadi 32,79 kali pada tahun 2018, kemudian mengalami peningkatan lagi pada tahun 2019 sebesar 2,63\% dari 32,79 kali pada tahun 2018 menjadi 35,42 kali pada tahun 2019. Pada tahun 2019 perusahaan Dharma Satya Nusantara Tbk mengalami peningkatan perputaran piutang sebesar $2,06 \%$ dari 13,15 kali pada tahun 2018 menjadi 15,21 kali pada tahun 2019. Hal serupa terjadi pada perusahaan Sampoerna Agro Tbk mengalami peningkatan perputaran piutang sebesar 1,07\% dari 25,01 kali dari tahun 2018 menjadi 26,08 kali pada tahun 2019. Namun peningkatan perputaran piutang tidak diikuti dengan peningkatan profitabilitas. Hal ini tidak sesuai dengan teori yang dikemukakan oleh Riyanto (1995) semakin besar jumlah piutang berarti semakin besar risiko yang didapat, tetapi bersamaan dengan itu semakin besar laba/ profitabilitas yang didapat.

Berdasarkan latar belakang penelitian yang telah dipaparkan, maka rumusan masalah dalam penelitian ini adalah: (1) Bagaimana pengaruh perputaran kas dan perputaran piutang terhadap profitabilitas pada perusahaan sub sektor yang terdaftar di BEI. (2) Bagaimana pengaruh perputaran kas terhadap profitabilitas pada sub sektor perkebunan yang terdaftar di BEI. (3) Bagaimana pengaruh perputaran piutang terhadap profitabilitas pada sub sektor perkebunan yang terdaftar di BEI.

Tujuan dari penelitian ini adalah untuk mengetahui hal-hal sebagai berikut: (1) Menguji pengaruh perputaran kas dan perputaran piutang terhadap profitabilitas pada sub sektor perkebunan yang terdaftar di BEI. (2) Menguji pengaruh perputaran kas terhadap profitabilitas pada sub sektor perkebunan yang terdaftar di BEI. (3) Menguji pengaruh perputaran piutang terhadap profitabilitas pada sub sektor perkebunan yang terdaftar di BEI.

\section{Hubungan Perputaran Kas dan Perputaran Piutang Terhadap Profitabilitas}

Menurut Kasmir (2010) rasio profitabilitas merupakan rasio yang digunakan untuk megukur bagaimana perusahaan dapat menghasilkan laba dengan sumber - sumber yang dimiliki oleh perusahaan yaitu total aktiva, penjualan, dan modal. Menurut Riyanto (1995) faktor - faktor yang mempengaruhi profitabilitas adalah modal kerja. Modal kerja yang ada pada perusahaan akan selalu berputar. Tingkat perputaran modal kerja yang tinggi akan mempengaruhi laba perusahaan akan meningkat, demikian juga pada tingkat profitabilitas akan meningkat pula. Dalam hal ini komponen dari modal kerja adalah kas dan piutang yang berpengaruh terhadap keuntungan/ profitabilitas yang didapat.

$\mathrm{H}_{1}$ : Ada pengaruh perputaran kas dan perputaran piutang terhadap profitabilitas.

\section{Hubungan Perputaran Kas Terhadap Profitabilitas}

Menurut Gill dalam (Kasmir, 2010) rasio perputaran kas memiliki fungsi untuk mengukur tingkat tersedianya modal yang ada di perusahaan untuk membayar hutangnya dan untuk membiayai penjualannya. Perputaran kas adalah ukuran penggunaan kas dengan optimal yang dilakukan oleh perusahaan, sehingga perputaran kas yang cepat akan mengembalikan arus kas yang ditanam di dalam modal kerja. Perputaran kas menunjukkan kemampuan kas dalam menghasilkan keuntungan, sehingga dapat dilihat berapa kali uang kas berputar dalam satu periode. Tingkat perputaran kas yaitu perbandingan antara penjualan dengan rata - rata jumlah kas yang dimiliki. Semakin tinggi tingkat perputaran kas maka laba yang didapat akan semakin tinggi pula. Semakin tinggi tingkat perputarannya maka semakin tinggi tingkat penggunaan kasnya (Riyanto, 1995: 95).

$\mathrm{H}_{2}$ : Ada pengaruh perputaran kas terhadap profitabilitas 


\section{Hubungan Perputaran Piutang Terhadap Profitabilitas}

Menurut Kasmir (2010) bahwa perputaran piutang ini adalah rasio yang digunakan untuk menunjukkan keberhasilan dalam penagihan piutang. Piutang yang ada di perusahaan akan terus menerus berputar. Periode perputaran piutang tergantung dari syarat pembayarannya. Semakin lama syarat pembayaran tersebut maka semakin lama modal kembali menjadi kas karena masih terikat terhadap piutang. Semakin besar jumlah piutang yang diberikan berarti semakin besar risiko yang didapat, tetapi bersamaan dengan itu semakin besar laba yang didapat sehingga diikuti pula dengan meningkatnya profitabilitas (Riyanto, 1995).

$\mathrm{H}_{3}$ : Ada pengaruh perputaran piutang terhadap profitabilitas.

\section{Metode}

Penelitian ini menggunakan jenis desain penelitian kuantitatif kausal, yaitu menggambarkan hubungan sebab akibat antar variabel satu dengan variabel lainnya. Penelitian ini dilakukan untuk mengetahui pengaruh perputaran kas dan perputaran piutang terhadap profitabilitas pada perusahaan Sub Sektor Perkebunan.

Subjek dalam penelitian ini adalah perusahaan Sub Sektor Perkebunan di Bursa Efek Indonesia. Sedangkan objek dalam penelitian ini adalah perputaran kas (X1), perputaran piutang (X2), dan profitabilitas (Y).

Populasi dalam penelitian ini yaitu perusahaan Sub Sektor Perkebunan yang terdaftar di Bursa Efek Indonensia yang menyampaikan laporan keuangan secara periodik dari tahun 2017 sampai dengan 2019 sebanyak 14 perusahaan. Penggunaan populasi dalam penelitian ini dikarenakan jumlah perusahaan pada Sub Sektor Perkebunan jumlahnya terbatas.

Metode pengumpulan data yang digunakan dalam penelitian ini adalah metode pencatatan dokumen dengan cara mengumpulkan, mencatat serta mengkaji data keuangan tahunan perusahaan sub sektor perkebunan yang terdaftar di Bursa Efek Indonesia tahun 2017 - 2019. Data yang diambil oleh peneliti berkaitan dengan masalah penelitian, yaitu perputaran kas, perputaran piutang dan profitabilitas yang dilihat berdasarkan pada data laporan keuangan yang diperoleh dari Bursa Efek Indonesia melalui website resmi dari Bursa Efek Indonesia yaitu www.idx.co.id.

Analisis data merupakan suatu kegiatan yang dilakukan setelah memperoleh data secara keseluruhan dari responden, selanjutnya menganalisis data tersebut yang telah terkumpul (Sugiyono, 2017). Dalam kegiatan melakukan analisis data yaitu dengan mengelompokkan data berdasaarkan variabel dan jenis respondennya, dan juga melakukan perhitungan mengenai menguji hipotesis yang diajukan. Teknik yang digunakan dalam penelitian ini analisis regresi linier berganda dengan bantuan program Statistical Package For Social Science (SPSS) versi 20 for Windows. Sebelum data diolah di regresi linier berganda, terlebih dahulu diuji dengan melakukan uji asumsi klasik, hal ini dilakukan karena syarat dari analisis regresi linier berganda adalah bebas dari asumsi-asumsi klasik. Uji asumsi klasik yang digunakan yaitu (1) Uji Normalitas, (2) Uji Multikolonieritas, (3) Uji Heteroskedastisitas dan (4) Uji Autokorelasi, data

\section{Hasil dan Pembahasan}

Berdasarkan hasil pengujian dengan menggunakan program SPSS 20 for Windows diperoleh hasil perngujian berupa ringkasan analisis regresi linier berganda pengaruh perputaran kas (X1) dan perputaran piutang (X2) terhadap profitabilitas (Y) seperti tampak pada Tabel 1. 
Tabel 1. Ringkasan Hasil Output Analisis Regresi Linier Berganda Pengaruh Perputaran Kas dan Perputaran Piutang Terhadap Profitabilitas

\begin{tabular}{|c|c|c|c|c|}
\hline Parameter & Nilai & $P^{\text {-value }}$ & Alpha & Keputusan \\
\hline $\mathbf{R y x}_{1} \mathbf{x}_{2}$ & 0,757 & 0,000 & 0,5 & Menolak Ho \\
& & & & \\
\hline $\mathbf{R}^{2} \mathbf{y x}_{1} \mathbf{x}_{2}$ & 0,573 & - & - & Menolak Ho \\
\hline $\mathbf{P y x}_{1}$ & 0,729 & 0,000 & 0,5 & Menolak Ho \\
& & & & \\
\hline $\mathbf{P}^{2} \mathbf{y x}_{1}$ & 0,531 & - & - & Menolak Ho \\
& & & & \\
\hline $\mathbf{P y x}_{2}$ & 0,396 & 0,010 & 0,5 & Menolak Ho \\
& & & & \\
\hline $\mathbf{P}^{2} \mathbf{y x}_{2}$ & 0,156 & - & - & Menolak Ho \\
& & & & \\
\hline$\varepsilon$ & 0,427 & - & - & \\
\hline
\end{tabular}

Struktur hubungan pengaruh perputaran kas dan perputaran piutang terhadap profitabilitas Nampak pada Gambar 1

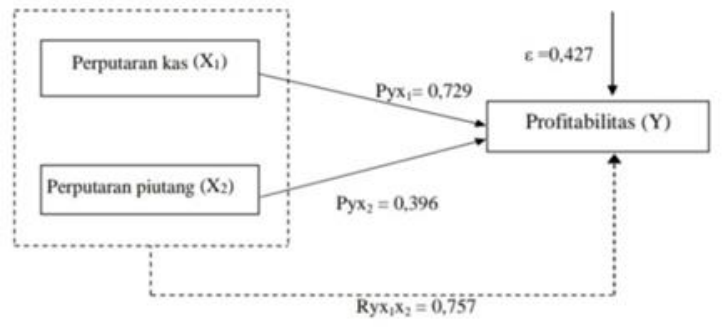

Gambar 1. Struktur hubungan pengaruh perputaran kas $\left(\mathrm{X}_{1}\right)$ dan perputaran piutang $\left(\mathrm{X}_{2}\right)$ terhadap Profitabilitas $(\mathrm{Y})$.

Hipotesis penelitian yang pertama yaitu ada pengaruh simultan dari perputaran kas (X1), dan perputaran piutang (X2) terhadap Profitabilitas pada Sub Sektor Perkebunan yang terdaftar di Bursa Efek Indonesia. Berdasarkan rekapan hasil uji regresi berganda diperoleh pada Tabel 1 menunjukkan hasil Ryx1x2 = 0,757 dengan p-value $0,000<0,05$, yang menyatakan bahwa menolak H0 yang berarti ada pengaruh signifikan dari perputaran kas (X1), dan perputaran piutang (X2) terhadap Profitabilitas. Besar sumbangan pengaruh simultan dari perputaran kas (X1), dan perputaran piutang (X2) terhadap Profitabilitas sebesar 0,573. Hasil tersebut menunjukkan bahwa sebesar 57,3\% Profitabilitas dipengaruhi oleh variabel perputaran kas (X1) dan perputaran piutang (X2). Sedangkan pengaruh dari variabel lain diluar perputaran kas (X1) dan perputaran piutang (X2) sebesar 42,7\%. Hal ini dapat disimpulkan bahwa variabel perputaran kas (X1), dan perputaran piutang (X2) secara bersama-sama berperan dalam meningkatkan profitabilitas (Y). Sehingga hipotesis pertama penelitian ini diterima.

Hipotesis penelitian yang kedua yaitu ada pengaruh dari perputaran kas terhadap profitabilitas pada Sub Sektor Perkebunan yang terdaftar di Bursa Efek Indonesia. Berdasarkan rekapan hasil uji regresi berganda yang diperoleh pada Tabel 4.2 yaitu besarnya hubungan perputaran kas (X1) terhadap profitabilitas (Y) sebesar 0,729 dengan p-value 0,000 
$<0,05$, nilai signifikansi ini lebih kecil dari pada probabilitas 0,05 , maka menolak H0, yang berarti terdapat pengaruh perputaran kas (X1) terhadap profitabilitas. Sehingga dapat disimpulkan bahwa variabel perputaran kas (X1) memiliki kontribusi terhadap profitabilitas (Y) dengan hubungan pengaruh sebesar $72,9 \%$ dan besar sumbangan pengaruh sebesar 53,1\%. Jadi dapat disimpulkan variabel Perputaran kas (X1) memiliki pengaruh positif signifikan secara parsial terhadap profitabilitas (Y). Sehingga hipotesis kedua dalam penelitian ini diterima.

Hipotesis penelitian ketiga yaitu ada pengaruh dari perputaran piutang terhadap profitabilitas pada Sub Sektor Perkebunan yang terdaftar di Bursa Efek Indonesia. Berdasarkan rekapan hasil uji regresi berganda yang diperoleh pada Tabel 4.2 yaitu besarnya hubungan perputaran piutang (X2) terhadap profitabilitas (Y) sebesar 0,396 dengan p-value $0,010<0,05$, yang menyatakan bahwa menolak Ho yang berarti ada pengaruh perputaran piutang (X2) terhadap profitabilitas (Y). Sehingga dapat disimpulkan bahwa variabel perputaran piutang (X2) memiliki kontribusi terhadap profitabilitas (Y) dengan hubungan pengaruh sebesar 39,6\% dan besar sumbangan pengaruh sebesar 15,6\%. Jadi dapat disimpulkan variabel perputaran piutang (X1) memiliki pengaruh positif signifikan secara parsial terhadap profitabilitas (Y). Sehingga hipotesis kedua dalam penelitian ini diterima.

Berdasarkan hasil uji regresi linier berganda diperoleh nilai konstanta $(\alpha)$ sebesar 0,301 ; nilai koefisien regresi perputaran kas $(\beta 1)$ sebesar 0,455 ; nilai koefisien regresi perputaran piutang $(\beta 2)$ sebesar 0,047 ; nilai koefisien error $(\varepsilon)$ sebesar 0,427 . Sehingga persamaan regresi diformulasikan sebagai berikut.

$\mathrm{Y}=0,301+0,455 \mathrm{X} 1+0,047 \mathrm{X} 2+0,427$

Interpretasi hasil analisis regresi linier berganda sebagai berikut. (1) Konstanta sebesar 0,301 artinya bahwa apabila perputaran kas (X1) dan perputaran piutang (X2) nilainya sama dengan nol, maka profitabilitas (Y) sebesar 0,301. (2) Nilai koefisien regresi perputaran kas $(\beta 1)$ sebesar 0,455 berpengaruh positif terhadap profitabilitas (Y). Hal ini mengandung arti bahwa setiap peningkatan perputaran kas (X1) satu satuan maka nilai profitabilitas (Y) akan mengalami peningkatan sebesar 0,455 dengan asumsi bahwa variabel bebas yang lainnya tetap. (3) Nilai koefisien regresi perputaran piutang ( $\beta 2$ ) sebesar 0,047 berpengaruh positif terhadap profitabilitas $(\mathrm{Y})$. Hal imi mengandung arti bahwa setiap peningkatan perputaran piutang (X2) satu satuan maka nilai profitabilitas (Y) akan mengalami peningkatan sebesar 0,047 dengan asumsi bahwa variabel bebas yang lainnya tetap. (4) Nilai koefisien error $(\varepsilon)$ sebesar 0,427 dengan asumsi bahwa masih ada variabel lain yang mempengaruhi profitabilitas selain perputaran kas (X1) dan perputaran piutang (X2).

Hasil penelitian ini menunjukkan bahwa ada pengaruh positif dan signifikan secara bersama-sama atau simultan dari perputaran kas (X1) dan perputaran piutang (X2) terhadap profitabilitas (Y) pada perusahaan Sub Sektor Perkebunan yang Terdaftar di Bursa Efek Indonesia tahun 2017-2019. Hal ini menunjukkan bahwa apabila perputaran kas dan perputaran piutang mengalami kenaikan bersama - sama akan diikuti dengan kenaikan profitabilitas. Hasil penelitian ini sejalan dengan teori yang dikemukakan oleh Riyanto (1995) bahwa faktor - faktor yang mempengaruhi profitabilitas adalah modal kerja. Modal kerja yang ada di perusahaan akan selalu berputar. Semakin tinggi tingkat perputaran modal kerja akan berdampak pada profitabilitas. Dalam hal ini komponen dari modal kerja adalah kas dan piutang yang berpengaruh terhadap profitabilitas. Sehinggaa jika perusahaan mampu mengelola perputaran kas dan perputaran piutang dengan efektif maka tidak menutup kemungkinan laba yang akan diperoleh akan terus mengalami peningkatan pada tahun tahun yang akan datang. Hasil penelitian ini juga sejalan dengan hasil penelitian yang dilakukan oleh Nurmawardi dan Lubis (2018) yang menyatakan bahwa variabel perputaran 
kas dan variabel perputaran piutang berpengaruh secara simultan dan signifikan terhadap profitabilitas.

Berdasarkan hasil penelitian yang telah dilakukan menunjukkan bahwa terdapat pengaruh positif yang signifikan antara perputaran kas (X1) terhadap profitabilitas (Y) pada perusahaan Sub Sektor Perkebunan yang Terdaftar di Bursa Efek Indonesia tahun 20172019. Hasil penelitian ini menunjukkan bahwa tingginya tingkat perputaran kas akan berdampak pada peningkatan profitabilitas. Hasil penelitian ini sejalan dengan teori yang dikemukakan oleh teori Riyanto (1995) menyatakan bahwa semakin tinggi tingkat perputaran kas maka semakin tinggi tingkat penggunaan kasnya dan akan dapat memperoleh laba yang semakin tinggi pula. Dalam hal ini menunjukkan bahwa kondisi perusahaan dapat menggunakan kas secara efektif dan efisien pada setiap periode karena tingkat perputaran kas yang tinggi mampu meningkatkan nilai profitabilitas. Apabila tingkat perputaran kas yang ada di perusahaan terus mengalami peningkatan maka hal tersebut membuat perusahaan tidak akan kesulitan dalam memenuhi kewajiban jangka pendeknya. Hasil penelitian ini sejalan dengan penelitian yang dilakukan oleh Yulistiani dan Suryantini (2016) yang menyatakan bahwa perputaran kas berpengaruh positif dan signifikan terhadap profitabilitas.

Hasil penelitian ini menunjukkan ada pengaruh positif dan signifikan perputaran piutang terhadap profitabilitas pada perusahaan Sub Sektor Perkebunan yang terdaftar di Bursa Efek Indonesia tahun 2017 - 2019. Hasil penelitian ini menunjukkan bahwa nilai profitabilitas mengalami peningkatan yang disebabkan karena perputaran piutang juga mengalami peningkatan. Hasil penelitian ini sejalan dengan teori yang dikemukakan oleh Riyanto (1995) bahwa perputaran piutang menunjukkan periode terikatnya modal kerja dalam piutang, dimana semakin cepat periode perputaran piutang menunjukkan semakin cepat perusahaan memperoleh keuntungan dari penjualan kredit yang dilakukan perusahaan, sehingga profitabilitas mengalami peningkatan. Hal yang menyebabkan perputaran piutang memiliki pengaruh terhadap profitabilitas, karena perusahaan mampu mengelola perputaran piutang dengan efektif dan efisien, dan perusahaan mampu memperkirakan piutang yang mungkin tidak dapat tertagih dengan baik, serta perusahaan mampu meminimalisir apabila ada kredit macet sehingga perputaran piutang tidak terganggu dan perusahaan akan tetap memperoleh keuntungan. Hal ini dapat dikatakan bahwa hasil penelitian ini sejalan dengan hasil penelitian yang dilakukan oleh Putra dan Wirajaya (2013) yang menyatakan bahwa secara parsial perputaran piutang berpengaruh positif terhadap profitabilitas. Discussion is the most important of scientific articles. The purpose of the discussion is to answer the research problem, interpret the findings from research into a collection of existing knowledge, and develop new theories, or modify existing theories.

\section{Simpulan dan Saran}

Berdasarkan hasil penelitian pada perusahaan Sub Sektor Perkebunan yang Terdaftar di Bursa Efek Indonesia tahun 2017 - 2019 yang telah dijelaskan sebelumnya, maka dapat disimpulkan hal sebagai berikut. (1) Perputaran kas dan perputaran piutang berpengaruh signifikan secara simultan terhadap Profitabilitas pada perusahaan Sub Sektor Perkebunan yang Terdaftar di Bursa Efek Indonesia. (2) Perputaran kas berpengaruh positif dan signifikan terhadap profitabilitas pada perusahaan Sub Sektor Perkebunan yang Terdaftar di Bursa Efek Indonesia. (3) Perputaran piutang berpengaruh positif dan signifikan terhadap profitabilitas pada perusahaan Sub Sektor Perkebunan yang Terdaftar di Bursa Efek Indonesia.

Berdasarkan hasil penelitian dan simpulan maka saran yang dapat disampaikan adalah sebagai berikut. (1) Bagi investor penelitian ini diharapkan dapat memberikan informasi kepada investor mengenai keputusan investasinya sebelum menanamkan modal yang dimiliki kepada perusahaan. Tindakan yang perlu dilakukan oleh investor yaitu dengan melakukan 
analisis secara mendalam mengenai profitabilitas perusahaan. Dalam hasil penelitian ini terdapat dua aspek penting yang dapat mempengaruhi profitabilitas yaitu perputaran kas dan perputaran piutang. Oleh karena itu seorang investor diharapkan dapat memperhatikan bagaimana perkembangan perputaran kas dan perputaran piutang sehingga dapat memberikan keputusan yang tepat mengenai investasi yang akan dilakukan oleh investor. Bagi peneliti selanjutnya diharapkan dapat mengembangkan penelitian ini dengan menambah variabel variabel lain yang dapat mempengaruhi profitabilitas. Selain itu populasi penelitian dan juga sampel yang diteliti tidak dikhususkan pada perusahaan yang terdaftar di Bursa Efek Indonesia pada tahun 2017 - 2019, tetapi dapat menggunakan tahun yang lain untuk diteliti.form.

\section{Daftar Pustaka}

Kasmir. (2010). Pengantar Manajemen Keuangan. Cetakan Ke-1. Jakarta: Kencana Prenada Media Group.

Kasmir. (2011). Analisis Laporan Keuangan. Jakarta: Rajawali Pers.

Narayana, I. P. (2013). Pengaruh Perputaran Kas, Loan to Deposit Ratio, Tingkat Permodalan dan Leverage Terhadap profitabilitas Bank Perkreditan Rakyat (BPR) Se-Kota Denpasar Periode 2009-2011. E-Jurnal Akuntansi Universitas Udayana, 3(2), 334350

Nurmawardi, F., \& Iman Lubis. (2018). Pengaruh Perputaran Kas dan Perputaran Piutang Terhadap Profitabilitas PT. Indofood Sukses Makmur TBK. Jurnal Madani: Ilmu Pengetahuan, Teknologi, dan Humaniora, 2(1), 103-112.

Priantiningtias, Z. Z., \& Sonang Sitohang. (2017). Perputaran Modal Kerja, Piutang, Kas, dan Pengaruhnya Terhadap Profitabilitas. Jurnal Ilmu dan Riset Manajemen, 6(4).

Putra, I. W., \& I. G. Ary Wirajaya. (2013). Pengaruh Tingkat Perputaran Kas, Piutang dan Jumlah Nasabah Kredit Pada Profitabilitas LPD di Kecamatan UBUD. E-Jurnal Akuntansi Udayana, 3(1), 119-135.

Riyanto, B. (1995). Dasar - dasar Pembelanjaan Perusahaan. Yogyakarta:BPFE.

Santoso, C. E. (2013). Perputaran Modal Kerja dan Perputaran Piutang Pengaruhnya Terhadap Profitabilitas Pada PT. Pegadaian (Persero). Jurnal EMBA, 1(4) 1581-1590.

Sugiyono. (2017). Statistika Untuk Penelitian. Bandung: Alfabeta.

Ulum, M. M., \& Ulil Hartono. (2017). Pengaruh Cash Conversion Cycle, Inventory Turnover, Average Payment Period, Cash Turnover dan Leverage Terhadap Profitablitas Perusahaan (Studi pada Perusahaan Sektor Trade, Service, \& Investment Periode 2012-2015). Jurnal Ilmu Manajemen, 5(4).

Yulistiani, I. G., \& N. P. Suryantini. (2016). Pengaruh Perputaran Kas, Kecukupan Modal dan Risiko Operasi Terhadap Profitabilitas Pada Perusahaan Perbankan di BEI. EJurnal Manajemen Unud, 5(4). 